\title{
RNF20 Gene
}

National Cancer Institute

\section{Source}

National Cancer Institute. RNF20 Gene. NCI Thesaurus. Code C102915.

This gene plays a role in polyubiquitination, histone modification and transcriptional regulation. 